\title{
Conservation and genetics of New Zealand parakeets
}

\author{
S. J. TRIGGS and C. H. DAUGHERTY
}

\section{Summary}

Recent genetic analysis of New Zealand Cyanoramphus parakeets has direct implications for conservation management. A subspecies of Yellow-crowned Parakeet, Forbes's Parakeet $C$. auriceps forbesi, is genetically distinct from mainland Yellow-crowned Parakeets $C$. a. auriceps and should be elevated to species status. Even amongst mainland populations of Yellow-crowned Parakeets there was extensive genetic diversity. Interspecific hybridization is a major concern of Cyanoramphus conservation. The near-extinction of Forbes's Parakeets by genetic swamping through hybridization with Chatham Islands Red-crowned Parakeets C. novaezelandiae chathamensis has been averted by active management, involving culling of hybrid and Red-crowned Parakeets and habitat enhancement. Despite two decades of hybridization between these species a distinct Forbes genetic type still exists, probably due to a tendency for hybrids to backcross with Red-crowned Parakeets. Hybridization between Cyanoramphus species may also be a problem in other highly modified habitats, such as parts of the Auckland Islands. More information is needed to determine the extent of this problem. Captive populations include a significant proportion of interspecific hybrids and therefore should not be used as founder stock for releases into the wild, as has been done in the past. The Orange-fronted Parakeet should be reinstated as a separate species, Cyanoramphus malherbi, rather than a colour morph of Yellow-crowned Parakeet, at least until conclusive evidence is available to resolve the question of its taxonomic status. The conservation of this very rare species (and indeed all species of Cyanoramphus) has been severely handicapped by lack of scientific information on which to base management decisions.

\section{Introduction}

Quantitative analysis of genetic diversity within and among species has become feasible since the development of biochemical genetic techniques over the last two decades. Analysis of genetic diversity is becoming increasingly important as conservation managers strive to preserve genetic diversity within as well as among species (Schonewald-Cox et al. 1983, Soulé 1987). Genetic conservation aims to maintain genetic diversity within and among populations by retaining large populations and preserving natural gene-flow amongst populations; by conserving populations throughout the geographic range of the species; and by preventing unnatural mixing of different genetic types during establishment of new populations or by interspecific hybridization. Management of genetic diversity requires correct identification of species and relationships among species (e.g. Avise and Nelson 1989, Daugherty et al. 1990) and knowledge of the geographic structure of populations (e.g. Vrijenhoek et al. 1985). 
The New Zealand parakeet fauna is currently thought to comprise three extant species and six subspecies of the genus Cyanoramphus (Oliver 1955, Taylor et al. 1986). Two further subspecies (C. novaezelandiae saissetti and C. n. cooki: Figure 1 ) occur beyond New Zealand and its outlying islands, and are not included in this discussion. Cyanoramphus parakeets face a variety of threats to survival (Taylor 1985), and therefore exemplify a number of conservation management problems.

Five taxa occur naturally on only a single island or island group (Figure 1): the Antipodes or Unicolour Parakeet $C$. unicolor, the Red-crowned Parakeets of the Kermadec, Chathams, and Antipodes Islands ( $C$. novaezelandiae cyanurus, $C$. $n$. chathamensis, $C$. n. hochstetteri), and the endangered Forbes's Parakeet $C$. auriceps forbesi, this last having been reduced to fewer than 30 individuals in the early 1970 os because of habitat loss and predation (Taylor 1975). The other island forms are not presently in low numbers, but must be considered vulnerable, as an accidental introduction of rodents, mustelids or cats could have a devastating impact. Apart from Forbes's Parakeet, no active management of parakeets has been undertaken on any of the islands, although recent habitat enhancement by removal of mammalian browsers or predators has had a positive impact on parakeet numbers on some islands.

The nominate subspecies of Yellow-crowned Parakeet C. a. auriceps and Red-crowned Parakeet $C$. $n$. novaezelandiae are widespread on the main islands of New Zealand and the Auckland Islands (Figure 1), but are still threatened in many locations by habitat modification and destruction, predation by introduced mammals, and possibly competition from introduced species. Very little is known of the biology of any of the species, other than from a few ecological (Taylor 1975, Nixon 1982, Greene 1988) and systematic studies (Nixon 1981, 1982). Even the exact distribution of the species on the main islands of New Zealand is difficult to ascertain, as many observations in the "Atlas of Bird Distribution in New Zealand" (Bull et al. 1985) do not distinguish between the species. Management of mainland parakeets has been limited to captive breeding of all species and release of captive Red-crowned Parakeets onto various islands and into mainland forests (Taylor 1985).

The Orange-fronted Parakeet was previously held to be a separate species, C. malherbi, but is now regarded as a colour morph of $C$. a. auriceps (Taylor et al. 1986). Little is known of its status in the wild, but the limited number of recent sightings suggests that it is very rare.

The aim of this paper is to document the implications for conservation and management of a recent biochemical genetic study by the authors on the systematics and genetic diversity of New Zealand parakeets.

\section{Methods}

We used protein (allozyme) electrophoresis to assess genetic variation at 21 allozyme loci (including six polymorphic loci) from blood samples of all New Zealand species and subspecies (Table 1 ) of Cyanoramphus using the methods of Triggs et al. (1989). A dendrogram summarizing genetic relationships among all the populations was constructed from Nei's (1978) unbiased genetic distances 


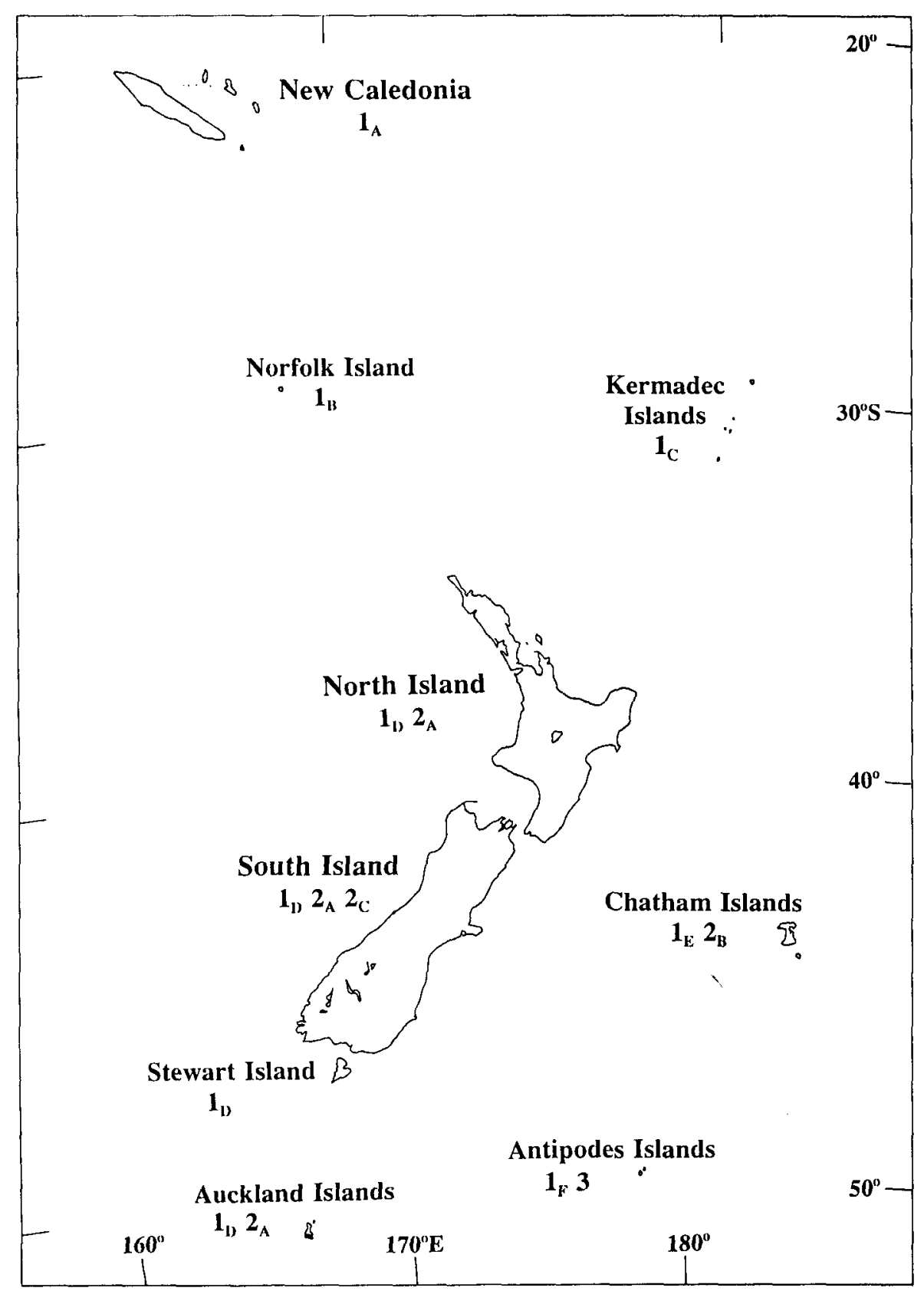

Figure 1. Distribution of extant Cyanoramphus parakeets. $I_{A}$, New Caledonian Redcrowned Parakeet $C$. novaezelandiae saissetti; $1_{B}$, Norfolk Island Red-crowned Parakeet C. $n$. cooki; $1_{C}$, Kermadec Islands Red-crowned Parakeet C. $n$. cyanurus; $I_{D}$, New Zealand Red-crowned Parakeet $C$. $n$. novaezelandiae; $\mathbf{1}_{E}$, Chatham Islands Red-crowned Parakeet C. $n$. chathamensis; $1_{\mathrm{F}}$, Antipodes Islands Red-crowned Parakeet $C$. $n$. hochstetteri; $\mathbf{2}_{\mathrm{A}}$, New Zealand Yellow-crowned Parakeet, $C$. a: auriceps; $2_{\mathrm{B}}$, Forbes's Parakeet $C$. a. forbesi $=$ C. forbesi; $2_{\mathrm{C}}$, Orange-fronted Parakeet C. a. auriceps? = C. "malherbi"; 3, Antipodes Islands or Unicolour parakeet C. unicolor. 
Table 1. Locations and sample sizes of populations of Cyanoramphus parakeets sampled for electrophoretic analysis.

\begin{tabular}{|c|c|}
\hline Species and location & Sample size \\
\hline \multicolumn{2}{|c|}{ Cyanoramphus auriceps auriceps (Yellow-crowned Parakeet) } \\
\hline Chetwode Islands, Cook Strait & 22 \\
\hline Little Barrier Island, North Island & 3 \\
\hline Captive & 3 \\
\hline Lake Sumner Forest Park, South Island & 8 \\
\hline Fiordland, South Island & 22 \\
\hline \multicolumn{2}{|c|}{ C. auriceps $=$ malherbi (Orange-fronted Parakeet) } \\
\hline - Lake Sumner Forest Park, South Island & 4 \\
\hline \multicolumn{2}{|l|}{ C. auriceps forbesi (Forbes's Parakeet) } \\
\hline Mangere Island, Chatham Island & 19 \\
\hline \multicolumn{2}{|c|}{ C. novaezelandiae novaezelandiae (Red-crowned Parakeet) } \\
\hline Poor Knights Islands, North Island & 27 \\
\hline Little Barrier Island, North Island & 12 \\
\hline Three Kings Islands, North Island & 7 \\
\hline Whale Island, North Island & 11 \\
\hline Captive & 18 \\
\hline \multicolumn{2}{|c|}{ C. novaezelandiae cyanurus (Kermadec Red-crowned Parakeet) } \\
\hline Kermadec Islands & 1 \\
\hline \multicolumn{2}{|c|}{ C. novaezelandiae chathamensis (Chatham Islands Red-crowned Parakeet) } \\
\hline South-east Island, Chatham Islands & 10 \\
\hline \multicolumn{2}{|c|}{ C. novaezelandiae hochstetteri (Antipodes Red-crowned Parakeet) } \\
\hline Captive & 2 \\
\hline \multicolumn{2}{|l|}{ C. $n$. novaezelandiae $\times$ C. a. auriceps hybrids } \\
\hline Little Barrier Island, North Island & 2 \\
\hline \multicolumn{2}{|l|}{ C. $n$. chathamensis $\times$ C. a. forbesi hybrids } \\
\hline Mangere Island, Chatham Islands & 28 \\
\hline \multicolumn{2}{|l|}{ C. a. auriceps $\times C$. "malherbi" hybrids } \\
\hline Captive & 7 \\
\hline \multicolumn{2}{|l|}{ C. unicolor (Antipodes or Unicolour Parakeet) } \\
\hline Captive & 5 \\
\hline
\end{tabular}

using the UPGMA algorithm of the BIOSYS-1 program (Swofford and Selander 1981).

\section{Results}

Genetic diversity and taxonomy

The present taxonomic distinctions between $C$. auriceps, $C$. novaezelandiae and C. unicolor were supported by the allozyme data. A large genetic distance was 


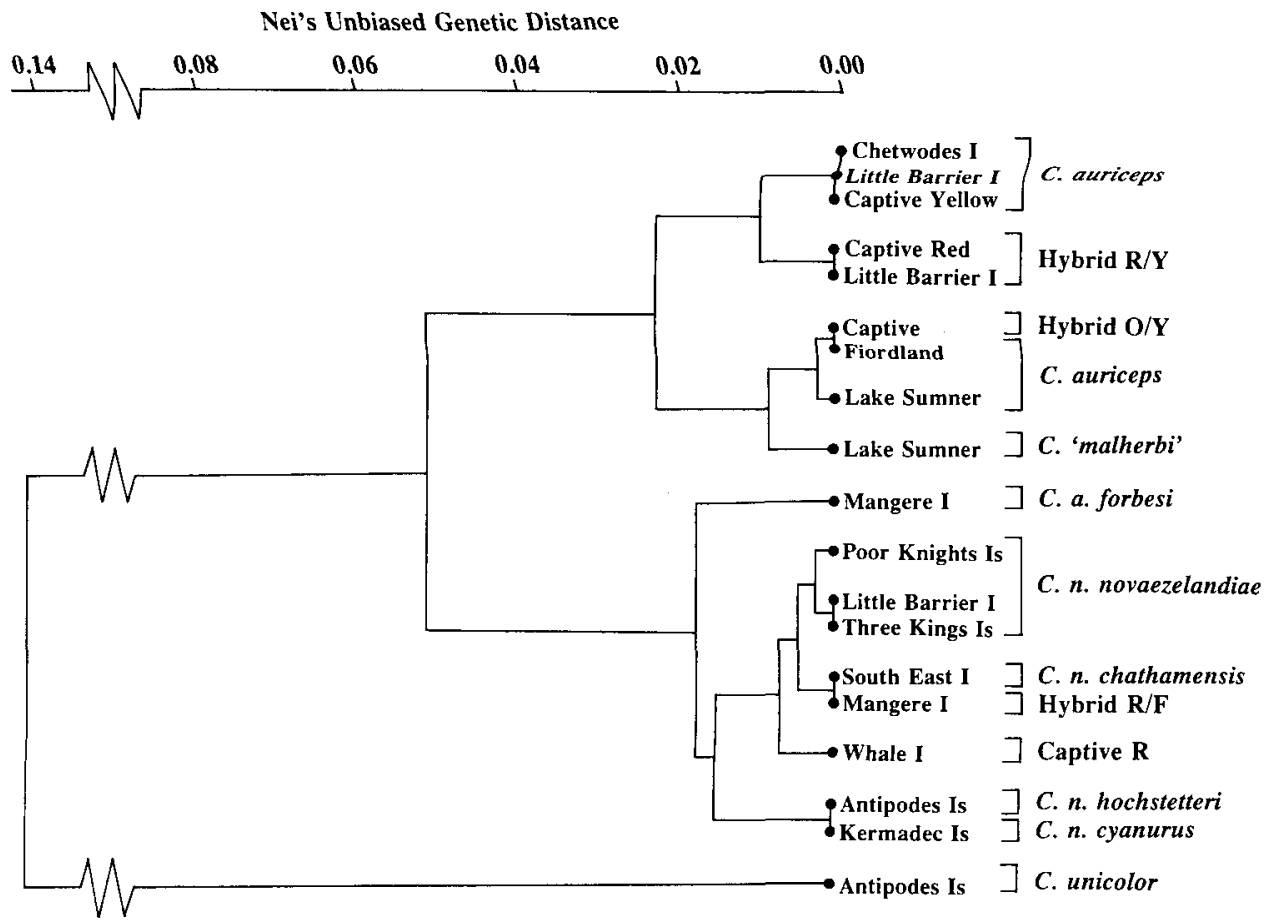

Figure 2. Dendrogram of genetic relationships among New Zealand Cyanoramphus parakeets. R, C. novaezelandiae; Y, C. a. auriceps; O, C. "malherbi", F, C. a. forbesi.

found between $C$. unicolor and other species (Figure 2), in agreement with its distinctive morphology (Falla et al. 1978) and behaviour (Taylor 1985). The observed Nei's genetic distance of 0.05 between $C$. auriceps and $C$. novaezelandiae is about average for other congeneric avian species (Barrowclough 1983, Barrowclough et al. 1985).

However, the genetic diversity within the species is not adequately described by the present subspecific classification. Subspecies of Red-crowned Parakeet, despite wide geographic separation (Figure 1), are genetically very similar (Figure 2). In contrast, Yellow-crowned Parakeets from South Island differ from North Island/Marlborough Sounds populations by as much as the difference between subspecies of Red-crowned Parakeets. In general, conservation programmes should aim to preserve the geographic structure of genetic diversity (e.g. Vrijenhoek et al. 1985). Thus, artificial mixing of northern and southern Yellow-crowned Parakeets should be avoided if natural genetic diversity is to be conserved. For example, new populations to be established on island refuges should be founded with parakeets from geographically close areas.

\section{Taxonomic Status of Forbes's Parakeet}

The island subspecies of Yellow-crowned Parakeet, C. a. forbesi, is genetically very different $\left(\mathrm{Nei}^{\prime} \mathrm{s} \mathrm{D}=0.05\right)$ from other Yellow-crowned Parakeets. Forbes's 
Parakeet was originally described as a species (Rothschild 1893), but was listed without reason as a subspecies of $C$. auriceps by Oliver (1930). Morphological evidence also supports the distinctiveness of Forbes's Parakeets: they overlap in size with Red-crowned Parakeets but are significantly larger than and differ in colour from mainland Yellow-crowned Parakeets (Fleming 1939, Nixon 1982). On the basis of these differences and because Oliver (1930) did not give data to justify merging Forbes's and Yellow-crowned Parakeets, Forbes's Parakeet should be reinstated as a separate species, C. forbesi. An increase in the conservation importance of this species should be recognized because of its genetic uniqueness.

\section{Status of Auckland Islands parakeets}

Cyanoramphus from the Auckland Islands have not been evaluated by genetic or other systematic techniques. The Auckland Islands Red-crowned Parakeet was named as a subspecies in Oliver (1930) but not in Oliver (1955). In light of the genetic diversity within mainland $C$. a. auriceps and the specific distinction of Forbes's Parakeet, the status of the Yellow-crowned Parakeets on the Auckland Islands should be investigated, especially as this form is said to be rare and hybridizing frequently with Red-crowned Parakeets on the modified islands of the group (Taylor 1975, G. Elliott verbally). Very little information has been published on the parakeets of the Auckland Islands. Their taxonomic status, ecology and genetics warrant further investigation, so that informed decisions on their future management can be made.

\section{Taxonomic status of the Orange-fronted Parakeet}

The major taxonomic problem of New Zealand parakeets, the status of the Orange-fronted Parakeet, exemplifies a complex (and still unresolved) conservation problem arising from lack of basic biological knowledge of this species.

Orange-fronted Parakeets, which were regarded as a separate species $C$. malherbi until recently, have been reported from scattered locations in South Island (Harrison 1970) and possibly also in North Island (Taylor 1985). Since 1966 the few confirmed sightings have been made only in the Arthur's Pass/ Lake Sumner region of South Island (Read and McClelland 1984, C. O'Donnell and P. Dilks verbally).

Orange-fronted are distinguished from Yellow-crowned Parakeets by the orange rather than red frontal band and rump patches, as well as by differences in the green plumage and yellow crown coloration (Holyoak 1974). Early reports suggesting that Orange-fronted were smaller than Yellow-crowned Parakeets (Oliver 1955) have not been supported by more recent studies of museum specimens (Holyoak 1974, Nixon 1981). Three wild-caught male Orange-fronted Parakeets, however, had a significantly shorter mean bill length $(14.1 \pm 0.67 \mathrm{~mm})$ than seven sympatric wild male Yellow-crowned Parakeets $(15.1 \pm 0.26 \mathrm{~mm})$ from the Lake Sumner area $(t$-test, $P<0.05)$. Incorrect sexing and/or differences in measuring technique between observers are possible sources of errors. Alternatively, the larger bill length of Yellow-crowned 
Parakeets recorded from Lake Sumner Forest Park may reflect geographic differences in bill length among populations of Yellow-crowned Parakeet, as the average bill length of museum specimens of Yellow-crowned Parakeets (13.8 mm: Nixon 1981, 1982) was smaller than that of wild Yellow-crowns from Lake Sumner, whereas Orange-fronted Parakeets from Lake Sumner had more similar bill lengths to museum specimens of Orange-fronted Parakeet (13.4 $\pm 0.5 \mathrm{~mm}$ : Nixon 1981, 1982). Unfortunately, the origin of the museum specimens is unknown.

Holyoak (1974) first suggested that the Orange-fronted Parakeet might be a colour morph of the Yellow-crowned Parakeet and not a separate species. This hypothesis is consistent with breeding studies of captive birds, which showed that colour differences between the "species" are controlled by a single variable gene (Taylor et al. 1986). However, colour variation may often be encoded by one or a few genes (Holyoak 1974, Nixon 1982), even between species (e.g. Tauber and Tauber 1977). The breeding studies showing apparent single-locus control of orange/yellow coloration (Taylor et al. 1986) are therefore not a test of the specific status of the Orange-fronted Parakeet, as they relate to no presently accepted definition of a species.

Very little is known of the ecology or behaviour of Orange-fronted Parakeets in the wild, although some differences in behaviour from Yellow-crowned Parakeets have been observed (D. Crouchley, A. Cox and D. Mudge verbally). Single species flocks of Orange-fronted Parakeets have been seen (Fleming 1980, C. O'Donnell verbally) and two Orange-fronted $\times$ Orange-fronted Parakeet nesting pairs have been recorded from Lake Sumner Forest Park, compared to a single Orange-fronted $\times$ Yellow-crowned Parakeet pair. As only about $7 \%$ of observed parakeets in this area are Orange-fronted, the probability of these pairings occurring by chance if Orange-fronted and Yellow-crowned Parakeet are mating randomly (i.e. the same species) is only 0.013 . The mixed pair may have also resulted from the removal for captive breeding of the original mate of the Orange-fronted Parakeet female just prior to egg-laying (D. Crouchley verbally). No chicks were hatched from this nest. Other pairs of Orange-fronted Parakeets have been seen in the Hawdon Valley (Read and McClelland 1984, C. O'Donnell verbally).

Although the results of genetic analysis (Figure 2) suggest that Orange-fronted Parakeets are separated from both sympatric and geographically distant South Island Yellow-crowned Parakeets by as much as the genetic distance between subspecies of Red-crowned Parakeets, this difference was not significant. It was based on a small sample size, and Orange-fronted Parakeets fell within the overall Yellow-crowned Parakeet group. Further analyses using larger sample sizes or more sensitive genetic techniques are needed to clarify the genetic relationship between the two forms.

Thus, the available evidence leads to no firm resolution of the status of the Orange-fronted Parakeet (i.e. threatened species or colour morph). In view of the serious consequences of incorrect classification as a colour morph, however, specific status should be retained until conclusive evidence to the contrary is produced.

Orange-fronted Parakeets have not been managed in the wild. The remaining three in captivity have been interbred with captive Yellow-crowned Parakeets 
(Taylor et al. 1986). The present captive breeding programme, based on Yellow-crowned/Orange-fronted Parakeet hybrids, should be reassessed in light of the precautionary reinstatement of the Orange-fronted Parakeet as a species.

This case study illustrates the necessity for information on all aspects of a species's biology (ecology, behaviour, genetic relationships, breeding) before even the most basic management decision (i.e. whether or not to manage) can be made. Such information is obviously best collected before the species becomes so rare that observation of its natural biology is exceedingly difficult.

\section{Hybridization between parakeet species}

\section{Hybridization in wild populations}

Although $C$. auriceps and C. novaezelandiae differ genetically (Figure 2), as well as morphologically (Nixon 1982) and behaviourally (Greene 1988), hybrids between the two species do occasionally occur in unmodified habitats (Veitch 1979), usually where one species is numerically dominant (Butler 1986, Sagar 1988). Hybrids can be distinguished by the mixture of yellow and red feathers on the crown. Suspected hybrids caught on Little Barrier Island were confirmed as hybrids by genetic analysis (Figure 2).

However, where natural habitats have been highly modified by humans, as on several of the Auckland Islands, hybridization may be relatively common between parakeet species (Taylor 1975, 1985). The extent of hybridization on the Auckland Islands is not well known and should be the subject of further study. Hybridization between species is not necessarily a concern to conservation, if it is occurring naturally (Cade 1983). However, unnaturally high levels caused by human modification of habitats can be as much a threat to species survival as more obvious impacts such as predation. This is particularly true where one species is rare, as in the case of Forbes's Parakeet (discussed below), because genetic swamping of the rarer species can lead to extinction of the natural genotype.

\section{Hybridization between Forbes's and Chatham Island Red-crowned Parakeets}

The most critically endangered of the New Zealand parakeets is Forbes's Parakeet, which is known only from Little Mangere and Mangere Islands in the Chatham Islands group. Fewer than 30 individuals remained by 1973 (Taylor 1975) following deforestation of Mangere Island and the introduction of cats in the early 1900s. Cats disappeared in the 1950 s and farming on Mangere was discontinued in 1968, when the island was made a Flora and Fauna Reserve (Taylor 1975). By this time there remained only a few hectares of forest, which is favoured by Forbes's Parakeet (Taylor 1975). Chatham Island Red-crowned Parakeets, which prefer more open habitat than Forbes's, rapidly recolonized Mangere as the modified vegetation (rank pasture) provided ample food.

Hybrids between Forbes's and Red-crowned Parakeets were first noticed in 1970, when Taylor (1975) estimated that $60 \%$ of parakeets on Mangere were hybrid and only $8 \%$ were Forbes's. Extreme habitat modification is thought to be a major factor causing this hybridization, as the different habitat preferences 
and behaviour of Forbes's and Red-crowned Parakeets under natural conditions (Taylor 1975, Nixon 1982) are presumed to result in ecological separation of the two species. Limited mate choice for the few remaining Forbes's Parakeets and the large imbalance in numbers between the two species in the early stages of recolonization of Mangere probably also promoted hybridization.

To protect the critically endangered Forbes's Parakeet, the New Zealand Wildlife Service began culling Red-crowned Parakeets and hybrids on Mangere in 1976. Revegetation of the island is also being attempted. Few hybrids are now seen there, although Red-crowned Parakeets apparently continue to invade the island and some hybridization continues. Although hybridization was not prevented by culling, the removal of hybrids and Red-crowned Parakeets did allow Forbes's Parakeet to increase in numbers to their present level of a few hundred, probably by reducing competition for mates and for overlapping food resources (Nixon 1982). Without management, Forbes's Parakeet (or at least parakeets predominantly of the Forbes's genetic type) may not have survived the extreme bottleneck of the early 1970 s without being swamped genetically by the numerically superior Red-crowns.

What has been the effect of this extensive hybridization and selective culling for over a decade? Does Forbes's Parakeet still exist or are the parakeets with yellow crowns, in reality, a mixture of Forbes's and Red-crowned Parakeet genotypes? To answer these questions, blood samples were collected from 19 Forbes's and 28 Chatham Islands Red-crowned $\times$ Forbes's hybrid Parakeets on Mangere Island, and 10 Chatham Islands Red-crowned Parakeets on nearby South-east Island, where Forbes's Parakeet does not occur (Table 1).

The unexpected finding (discussed earlier), that Forbes's and Red-crowned Parakeets are more closely related than Forbes's and Yellow-crowned Parakeets, made it difficult to assess possible introgression of genes from one species into the other. The position of Forbes's between Red-crowned and Yellow-crowned Parakeets in Figure 2 is not evidence that they are hybrids: a fixed allelic difference was found between Forbes's and Yellow-crowned Parakeets at a locus for which Red-crowned Parakeets were variable. Forbes's Parakeets, distinguished on morphological characteristics, have remained a genetically distinct group; they clustered outside all subspecies of Red-crowned Parakeet (Figure 2) and had significantly different gene frequencies from both Chatham Island Redcrowned Parakeets $\left(\chi^{2}=22.0, d f=3, P<0.0001\right)$ and hybrids $\left(\chi^{2}=22.5, d f=\right.$ $3, P<0.0001)$. Conversely, gene frequencies did not differ between hybrids and Red-crowned Parakeets $\left(\chi^{2}=4.5, d f=3, P=0.22\right)$, suggesting that hybrids tend to backcross to Red-crowned Parakeets, thus maintaining a degree of integrity in the Forbes's Parakeet gene pool. This result agrees with the observations of Nixon (1982: 184).

More sensitive tests, based on analysis of DNA, would be needed to estimate the degree of introgression of Red-crowned Parakeet genes into the Forbes's Parakeet gene pool. A definitive analysis would not be possible without samples from "pure" Forbes's Parakeets, taken before hybridization began. Such an analysis may now be possible using DNA extracted from museum specimens (Houde and Braun 1988).

Future management probably lies with monitoring numbers of Forbes's Parakeet and hybrids, taking positive action if numbers of Forbes's decline. Con- 
tinued increase in numbers of Forbes's to a level where the species is no longer threatened may now depend on the improvement and expansion of the forest on Mangere Island, ultimately returning to a pre-farming situation, when Mangere was totally forested and Forbes's was the predominant parakeet (Fleming 1939).

\section{Hybridization in captivity and release of captive stock}

In captivity hybridization occurs readily. Even the two parakeets from the Antipodes Islands, C. unicolor and C. novaezelandiae hochstetteri, which are extremely divergent in morphology, behaviour and genetics, have been hybridized in captivity. Although one of the conditions of permits to hold parakeets is that no hybridization between species be allowed, hybrids are nevertheless relatively common. Our genetic analysis of captive Red-crowned Parakeets further documents this problem. Although most of the captive Red-crowns sampled lacked the morphological characteristics of hybrids, genetically they proved to be a mixture of Red-crowned and Yellow-crowned Parakeet genotypes (Figure 2).

This hybridization in captive parakeets matters to conservation, because captive parakeets are used to restock natural habitats. Captive "Red-crowned Parakeets" liberated on Cuvier Island show morphological characteristics of hybrids (C. R. Veitch verbally). However, a liberation of captive Red-crowned Parakeets on Whale Island may have been more representative of the genetic type of wild Red-crowned Parakeets (Figure 2). Other populations derived from captive stock have not yet been examined. No release programmes attempted to assess, a priori, which captive stock would have been most appropriate to release. In addition, captive stocks may have lost the integrity of local genetic types, have a limited genetic base if their populations are small, show maladaptive behavioural modifications, or carry diseases. Future releases of parakeets should be conducted using only wild or specially bred parakeet stocks.

\section{Conclusions and recommendations}

One of the most important goals of genetic studies for conservation is to quantify the genetic diversity within and among species. The correct identification of species is clearly an important first step in such studies.

The optimal management strategy to maintain genetic diversity is not always clear-cut. For example, genetic diversity can be maximized in a newly established population by choosing founders from a range of geographic populations, in the hope that increased diversity will promote adaptability (Cade 1983). On the other hand, unnatural outbreeding between very different genetic types may be deleterious if it disrupts co-adapted gene complexes (Shields 1982). For this reason, interspecific hybrids and intraspecific mixtures of individuals from genetically divergent populations should not be used to found new populations. Management decisions must be based on knowledge of the natural characteristics of the species in question.

Management of hybridizing species can also be controversial because hybridization is often a natural evolutionary process rather than a conservation "problem" (Cade 1983). For a species on the verge of extinction through genetic 
swamping, when the cause is thought to be unnatural (and reversible), management is warranted, as in the case of Forbes's Parakeet.

In light of these guidelines for genetic conservation and the results of our genetic analysis and taxonomic revision, we make the following recommendations for the conservation management of New Zealand Cyanoramphus parakeets.

(1) Maintain the high natural genetic diversity among populations of mainland Yellow-crowned Parakeets by avoiding artificial mixing of parakeets from different geographic regions.

(2) Investigate the genetic relationships between Auckland Islands and mainland parakeets. (This is particularly important for Yellow-crowned Parakeets, as this species shows extensive diversity among mainland populations.) Investigate the extent and causes of hybridization between Red-crowned and Yellow-crowned Parakeets on the Auckland Islands.

(3) Reinstate the Orange-fronted Parakeet as a species until adequate data are available to determine whether it is a species or a colour morph of Yellowcrowned Parakeet. Further research is needed urgently on the ecology, behaviour, distribution, and abundance of Orange-fronted Parakeets, so that appropriate management can be effected, if necessary. Re-evaluate the present captive breeding programme using Orange-fronted/Yellow-crowned hybrids.

(4) Elevate Forbes's Parakeet from subspecies to species and change its conservation status accordingly. Monitor the numbers of Forbes's Parakeet and hybrids, intervening to protect Forbes's Parakeet if necessary. Revegetation of Mangere Island is essential to secure the long-term survival of this species. More information is needed on the behaviour, reproductive success, survival and mate choice of Forbes's Parakeets and hybrids.

(5) Do not use captive parakeets as founders of new wild populations or to re-stock existing natural populations, unless they have been bred for this purpose from stock of known genetic origin.

\section{Acknowledgements}

For assistance with sample collections and for helpful advice and discussions we thank R. Powlesland, D. Brown, D. Crouchley, G. Elliott, A. and J. Garrick, A. Grant, T. Greene, E. and E. Heatherbell, P. Jansen, J. Lyle, P. McClelland, P. McKenzie, D. Merton, P. Moore, D. Mudge, R. Nilsson, C. O'Donnell, A. Southern, G. Taylor, A. Tennyson, C. Thorn, R. Thorpe, D. Veitch, S. Walker, and A. Wright. Permission to enter protected areas and to handle protected species were given by the Departments of Lands and Survey and Conservation, Hauraki Gulf Maritime Park Board, and Wildlife Service. We are grateful to Brian Bell, Mick Clout, Don Merton, Don Newman, Ralph Powlesland, and Richard Sadleir for commenting on the manuscript.

\section{References}

Avise, J. C. and Nelson, W. S. (1989) Molecular genetic relationships of the extinct Dusky Seaside Sparrow. Science 243: 646-648. 
Barrowclough, G. F. (1983) Biochemical studies of microevolutionary processes. Pp.223261 in A. H. Brush and G. A. Clark, eds. Perspectives in ornithology. Cambridge, U.K.: Cambridge University Press.

Barrowclough, G. F., Johnson, N. K. and Zink, R. M. (1985) On the nature of genic variation in birds. Pp.135-154 in R. F. Johnson, ed. Current ornithology, 2. New York: Plenum Press.

Bull, P. C., Gaze, P. D. and Robertson, C. J. R. (1985) Atlas of bird distribution in New Zealand. Wellington: Ornithological Society of New Zealand.

Butler, D. J. (1986) Hybrid parakeet on mainland. Notornis 33: 58-59.

Cade, T. J. (1983) Hybridisation and gene exchange among birds in relation to conservation. Pp.288-309 in C. M. Schonewald-Cox, S. M. Chambers, B. MacBryde and L. Thomas, eds. Genetics and conservation: a reference manual for managing wild animal and plant populations. Menlo Park, California: Benjamin/Cummings Publishing Co. Inc.

Daugherty, C. H., Cree, A., Hay, J. M. and Thompson, M. B. (1990) Neglected taxonomy and continuing extinctions of tuatara (Sphenodon). Nature 347: 177-179.

Falla, R. A., Sibson, R. B. and Turbott, E. G. (1978) The new guide to the birds of New Zealand. Auckland: Collins.

Fleming, C. A. (1939) Birds of the Chatham Islands. Part II. Emu 38: 492-509.

Fleming, C. A. (1980) Orange-fronted Parakeet: a record of flocking. Notornis 27: 388390.

Greene, T. (1988) Behavioural ecology of Red-crowned Parakeets and Yellow-crowned Parakeets on Little Barrier Island. M.Sc. thesis, University of Auckland, New Zealand.

Harrison, M. (1970) The Orange-fronted Parakeet (Cyanoramphus malherbi). Notornis 17: 115-25.

Holyoak, D. T. (1974) Cyanoramphus malherbi, is it a colour morph of C. auriceps? Bull. Brit. Orn. Club 94: 4-9.

Houde, P. and Braun, M. J. (1988) Museum collections as a source of DNA for studies of avian phylogeny. Auk 105: 773-776.

Nei, M. (1978) Estimation of average heterozygosity and genetic distance from a small number of individuals. Genetics 89: 583-590.

Nixon, A. J. (1981) The external morphology and taxonomic status of the Orange-fronted Parakeet. Notornis 28: 292-300.

Nixon, A. J. (1982) Aspects of the ecology and morphology of Cyanoramphus parakeets and hybrids from Mangere Island, Chatham Islands. M.Sc. thesis, Victoria University of Wellington, New Zealand.

Oliver, W. R. B. (1930) New Zealand birds. Wellington: Fine Arts (NZ) Ltd.

Oliver, W. R. B. (1955) New Zealand birds. 2nd edition. Wellington: A. H. and A. W. Reed.

Read, A. and McClelland, P. (1984) Orange-fronted Parakeets in Hawdon Valley, Arthur's Pass National Park. Notornis 31: 266-267.

Rothschild, W. (1893) Proc. Zool. Soc. London: 529.

Sagar, P. M. (1988) Some characteristics of Red-crowned Parakeets on the Poor Knights Islands. Notornis 35: 1-8.

Schonewald-Cox, C. M., Chambers, S. M., MacBryde, B. and Thomas, L., eds. (1983) Genetics and conservation: a reference manual for managing wild animal and plant populations. Menlo Park, California: Benjamin/Cummings Publishing Co. Inc.

Shields, W. M. (1982) Philopatry, inbreeding, and the evolution of sex. Albany: State University Press of New York.

Soulé, M. E., ed. (1987) Viable populations for conservation. Cambridge, U.K.: Cambridge University Press.

Swofford, D. L. and Selander, R. B. (1981) Biosys-1: A Fortran program for the comprehensive analysis of electrophoretic data in population genetics and systematics. $J$. Heredity 72: 281-283. 
Tauber, C. A. and Tauber, M. J. (1977) A genetic model for sympatric speciation through habitat diversification and seasonal isolation. Nature 268: 702-705.

Taylor, R. H. (1975) Some ideas on speciation in New Zealand parakeets. Notornis 22: 110-121.

Taylor, R. H. (1985) Status, habits, and conservation of Cyanoramphus parakeets in the New Zealand region. Pp.195-211 in P. J. Moors, ed. Conservation of island birds. Cambridge, U.K.: International Council for Bird Conservation (Techn. Publ. 3).

Taylor, R. H., Heatherbell, E. G. and Heatherbell, E. M. (1986) The Orange-fronted Parakeet (Cyanoramphus malherbi) is a colour morph of the Yellow-crowned Parakeet (C. auriceps). Notornis 33: 17-22.

Triggs, S. J., Powlesland, R. G. and Daugherty, C. H. (1989) Genetic variation and conservation of Kakapo (Strigops habroptilus: Psittaciformes). Conserv. Biol. 3: 92-96.

Veitch, C. R. (1979) Parakeet hybridization. Notornis 26: 395.

Vrijenhoek, R. C., Douglas, M. E. and Meffe, G. K. (1985) Conservation genetics of endangered fish populations in Arizona. Science 229: 400-402.

\section{S. J. TRIGGS}

Science and Research Division, Department of Conservation, P.O. Box 10-420, Wellington, New Zealand. Current address (but for reprints or correspondence, refer to Daugherty): Strategic Assessment Group, Ministry of Justice, P.O. Box 180, Wellington, New Zealand.

C. H. DAUGHERTY

School of Biological Sciences, Victoria University, P.O. Box 600, Wellington, New Zealand. 